\title{
Keratoconus: maternal age and social class
}

\author{
E. G. WOODWARD \\ From the Department of Contact Lens and Prosthetics, Moorfields Eye Hospital, \\ City Road, London EC1V 2PD
}

SUMMARY A group of patients (150) suffering from keratoconus were asked their mother's age at their birth. A statistically significant excess of older mothers as compared with the general population was found. The social class of the patients was found to have a distribution different from the general population, and it is suggested that this is related to the patient's maternal age.

After a number of years working with patients suffering from keratoconus the writer formed the impression that when first presenting for contact lens fitting patients were often accompanied by relatively aging parents. In order to test this impression patients entering a long-term study on the progression of keratoconus were asked the age of both parents at birth. Analysis of the findings from the first 50 patients strongly suggested there was a significantly different frequency distribution of the age of mothers at birth as compared with the general population, so the sample was expanded to a total of 150 patients.

Karseras and Ruben ${ }^{1}$ have reported that in their group of 75 patients most of the keratoconus patients were from social classes I and II (Registrar General's classification), whereas half of the total general population was from social class III. There is a relationship between social class and maternal age, and it is suggested that the social class findings in keratoconus may derive from the age of the mother.

\section{Patients and methods}

The first 50 patients in the study were all new referrals to the Keratoconus Clinic of the Department of Contact Lens and Prosthetics, Moorfields Eye Hospital. Although new referrals, they were not all newly diagnosed. Some had been diagnosed for several years and had been referred only when the management became more difficult, and some had newly moved to the London area. The mean age ( \pm SD) of this group was $24 \cdot 45 \pm 7 \cdot 29$. The mean age at diagnosis $( \pm \mathrm{SD})$ was $22 \cdot 18 \pm 7 \cdot 31$.

The further 100 patients questioned were consecutive patients attending the Keratoconus Clinic, some

Correspondence to Dr Woodward.
Table 1 Years of birth of patients in keratoconus sample

\begin{tabular}{llllll}
\hline Year & $\begin{array}{l}\text { Number of } \\
\text { patients }\end{array}$ & Year & $\begin{array}{l}\text { Number of } \\
\text { patients }\end{array}$ & Year & $\begin{array}{l}\text { Number of } \\
\text { patients }\end{array}$ \\
\hline 1909 & 1 & 1939 & 4 & 1952 & 4 \\
1913 & 1 & 1940 & 4 & 1953 & 6 \\
1919 & 1 & 1941 & 5 & 1954 & 9 \\
1927 & 1 & 1942 & 4 & 1955 & 5 \\
1928 & 2 & 1943 & 3 & 1956 & 4 \\
1929 & 1 & 1944 & 6 & 1957 & 6 \\
1930 & 1 & 1945 & 2 & 1958 & 4 \\
1932 & 1 & 1946 & 3 & 1959 & 9 \\
1933 & 1 & 1947 & 5 & 1960 & 8 \\
1935 & 2 & 1948 & 4 & 1961 & 9 \\
1936 & 1 & 1949 & 9 & 1962 & 3 \\
1937 & 3 & 1950 & 7 & 1963 & \\
1938 & 2 & 1951 & 5 & 1964 & 1
\end{tabular}

Total number of patients 150. Mean year of birth 1949. Standard deviation 12.36.

being old and some new patients. This gave a large spread of the years of birth for the total sample, i.e., 1909-65.

\section{Results}

The frequency distribution of the years of birth of the patients in the sample is shown in Table 1.

In making a comparison between the keratoconus sample and the general population this spread of years of birth presents a historiographic problem in that the pattern of child bearing has changed during that period. However, of the 150 patients 128 were born after 1939 and 112 were born during the period 1940-60. It thus seemed reasonable to look at the pattern of child bearing in 1940,1950, and 1960 (see Tables 2, 3, and 4). The source of the figures was the Registrar-General's Statistical 
Table 2 Pattern of child bearing 1940

\begin{tabular}{|c|c|c|c|c|c|c|c|c|}
\hline & \multicolumn{7}{|c|}{ Maternal age } & \multirow{2}{*}{ Total } \\
\hline & $<20$ & $20-24$ & $25-29$ & $30-34$ & $35-39$ & $40-44$ & $45-49$ & \\
\hline Number & 27043 & 144693 & 195863 & 136697 & 74264 & 23452 & 2016 & 604029 \\
\hline$\%$ & $4 \cdot 48$ & 23.95 & $32 \cdot 43$ & $22 \cdot 63$ & $12 \cdot 29$ & 3.88 & 0.33 & 100 \\
\hline
\end{tabular}

Table 3 Pattern of child bearing 1950

\begin{tabular}{|c|c|c|c|c|c|c|c|c|}
\hline & \multicolumn{7}{|c|}{ Maternal age } & \multirow{2}{*}{ Total } \\
\hline & $<20$ & $20-24$ & $25-29$ & $30-34$ & $35-39$ & $40-44$ & $45-49$ & \\
\hline Number & 31753 & 200406 & 244007 & 136767 & 87398 & 25796 & 1829 & 728556 \\
\hline$\%$ & $4 \cdot 36$ & $27 \cdot 51$ & $33 \cdot 57$ & $18 \cdot 77$ & $12 \cdot 00$ & $3 \cdot 54$ & 0.25 & 100 \\
\hline
\end{tabular}

Table 4 Pattern of child bearing 1960

\begin{tabular}{|c|c|c|c|c|c|c|c|c|}
\hline & \multicolumn{7}{|c|}{ Maternal age } & \multirow{2}{*}{ Total } \\
\hline & $<20$ & $20-24$ & $25-29$ & $30-34$ & $35-39$ & $40-44$ & $45-49$ & \\
\hline Number & 46067 & 229064 & 233579 & 143475 & 77261 & 17736 & 1315 & 748498 \\
\hline$\%$ & $6 \cdot 15$ & 30.50 & $31 \cdot 21$ & $19 \cdot 17$ & $10 \cdot 32$ & $2 \cdot 37$ & 0.18 & 100 \\
\hline
\end{tabular}

Table 5 Maternal age of general population compared with keratoconus sample

\begin{tabular}{|c|c|c|c|c|c|c|c|c|}
\hline & \multicolumn{7}{|c|}{ Maternal age } & \multirow{2}{*}{ Total } \\
\hline & $<20$ & $20-24$ & $25-29$ & $30-34$ & $35-39$ & $40-44$ & $45-49$ & \\
\hline General population 1940 & $4 \cdot 48$ & 23.95 & 32.43 & 22.63 & $12 \cdot 29$ & $3 \cdot 88$ & $0 \cdot 33$ & 100 \\
\hline General population 1950 & $4 \cdot 36$ & $27 \cdot 51$ & $33 \cdot 57$ & $18 \cdot 77$ & $12 \cdot 00$ & $3 \cdot 54$ & 0.25 & 100 \\
\hline General population 1960 & $6 \cdot 15$ & 30.50 & $31 \cdot 21$ & $19 \cdot 17$ & $10 \cdot 32$ & $2 \cdot 37$ & $0 \cdot 18$ & 100 \\
\hline Keratoconus sample & $3 \cdot 33$ & $12 \cdot 00$ & $24 \cdot 67$ & $31 \cdot 33$ & $22 \cdot 00$ & $5 \cdot 33$ & $1 \cdot 33$ & 100 \\
\hline
\end{tabular}

Table 6 Comparison of percentage of births to women over 30 and 35, general population and keratoconus sample

\begin{tabular}{lll}
\hline Year & $\begin{array}{l}\text { Maternal age } \\
30+\end{array}$ & $\begin{array}{l}\text { Maternal age } \\
35+\end{array}$ \\
\hline General population 1940 & 39.13 & 16.50 \\
General population 1950 & 34.58 & 15.79 \\
General population 1960 & 32.04 & 12.87 \\
General population 1973 & 20.04 & 6.5 \\
Keratoconus sample & 59.99 & 28.66 \\
\hline
\end{tabular}

Review from the Office of Population Census and Surveys.

As can be seen for the whole of the period under consideration the tendency was for women to have their children earlier and earlier.

Births by maternal age for the general population were then tabulated against the keratoconus sample (Table 5).

Since the mean year of birth for the sample was
1949 but the sample was skewed towards the later years, it seemed that the most valid comparison would be with the 1950 figures. Another way of presenting the figures would be to consider the percentage of births to women over 30 and over 35 (Table 6).

The number of babies born to women over the age of 35 has been falling both in absolute terms and as a percentage since 1965 , so if there is a connection between maternal age and the incidence of keratoconus there should be a fall in the number of cases presenting over the next few years.

STATISTICAL ANALYSIS

The $\chi^{2}$ goodness of fit test was used to test the hypothesis that maternal age distribution of keratoconus differs significantly from the maternal age distribution of the general population.

The choice of the model population might be questioned for appropriateness in that the RegistrarGeneral's population census data describes a population at fixed points in time $(1940,1950$, and 
Table $7 \quad \chi^{2}$ goodness of fit test applied to 1940 data

\begin{tabular}{|c|c|c|c|c|c|c|c|c|}
\hline \multirow{2}{*}{$\begin{array}{l}\text { Keratoconus } \\
\text { patients } \\
(n=150)\end{array}$} & \multicolumn{7}{|c|}{ Maternal age } & \multirow{2}{*}{ Total } \\
\hline & $<20$ & $20-24$ & $25-29$ & $30-34$ & $35-39$ & $40-44$ & $45-49$ & \\
\hline $\begin{array}{l}\text { Number observed } \\
\%\end{array}$ & $\begin{array}{l}5 \\
3 \cdot 33\end{array}$ & $\begin{array}{l}18 \\
12 \cdot 00\end{array}$ & $\begin{array}{l}37 \\
24 \cdot 67\end{array}$ & $\begin{array}{l}47 \\
31 \cdot 33\end{array}$ & $\begin{array}{l}33 \\
22 \cdot 00\end{array}$ & $\begin{array}{l}8 \\
5 \cdot 33\end{array}$ & $\begin{array}{l}2 \\
1 \cdot 33\end{array}$ & $\begin{array}{l}150 \\
100\end{array}$ \\
\hline $\begin{array}{l}\text { Number expected } \\
\%\end{array}$ & $\begin{array}{l}6 \cdot 72 \\
4 \cdot 48\end{array}$ & $\begin{array}{l}35.93 \\
23.95\end{array}$ & $\begin{array}{l}48 \cdot 65 \\
32 \cdot 43\end{array}$ & $\begin{array}{l}33.95 \\
22.63\end{array}$ & $\begin{array}{l}18 \cdot 44 \\
12 \cdot 29\end{array}$ & $\begin{array}{l}5 \cdot 82 \\
3 \cdot 88\end{array}$ & $\begin{array}{l}0.49 \\
0.33\end{array}$ & $\begin{array}{l}150 \\
100\end{array}$ \\
\hline
\end{tabular}

$\chi^{2}=30 \cdot 84$. Degrees of freedom $=5 . P<0.001$.

Table $8 \quad \chi^{2}$ goodness of fit test applied to 1950 data

\begin{tabular}{|c|c|c|c|c|c|c|c|c|}
\hline \multirow{2}{*}{$\begin{array}{l}\text { Keratoconus } \\
\text { patients } \\
(n=150)\end{array}$} & \multicolumn{7}{|c|}{ Maternal age } & \multirow{2}{*}{ Total } \\
\hline & $<20$ & $20-24$ & $25-29$ & $30-34$ & $35-39$ & $40-44$ & $45-49$ & \\
\hline $\begin{array}{l}\text { Number observed } \\
\%\end{array}$ & $\begin{array}{l}5 \\
3 \cdot 33\end{array}$ & $\begin{array}{l}18 \\
12 \cdot 00\end{array}$ & $\begin{array}{l}37 \\
24 \cdot 67\end{array}$ & $\begin{array}{l}47 \\
31 \cdot 33\end{array}$ & $\begin{array}{l}33 \\
22 \cdot 00\end{array}$ & $\begin{array}{l}8 \\
5 \cdot 33\end{array}$ & $\begin{array}{l}2 \\
1 \cdot 33\end{array}$ & $\begin{array}{l}150 \\
100\end{array}$ \\
\hline $\begin{array}{l}\text { Number expected } \\
\%\end{array}$ & $\begin{array}{l}6 \cdot 54 \\
4 \cdot 36\end{array}$ & $\begin{array}{l}41 \cdot 26 \\
27 \cdot 51\end{array}$ & $\begin{array}{l}50 \cdot 35 \\
33 \cdot 57\end{array}$ & $\begin{array}{l}28 \cdot 15 \\
18 \cdot 77\end{array}$ & $\begin{array}{l}18 \cdot 00 \\
12 \cdot 00\end{array}$ & $\begin{array}{l}5 \cdot 31 \\
3 \cdot 54\end{array}$ & $\begin{array}{l}0 \cdot 38 \\
0 \cdot 25\end{array}$ & $\begin{array}{l}150 \\
100\end{array}$ \\
\hline
\end{tabular}

$\chi^{2}=45 \cdot 402$. Degrees of freedom $=5 . P<0.001$.

Table $9 \chi^{2}$ goodness of fit test applied to 1960 data

\begin{tabular}{|c|c|c|c|c|c|c|c|c|}
\hline \multirow{2}{*}{$\begin{array}{l}\text { Keratoconus } \\
\text { patients } \\
(n=150)\end{array}$} & \multicolumn{7}{|c|}{ Maternal age } & \multirow{2}{*}{ Total } \\
\hline & $<20$ & $20-24$ & $25-29$ & $30-34$ & $35-39$ & $40-44$ & $45-49$ & \\
\hline $\begin{array}{l}\text { Number observed } \\
\%\end{array}$ & $\begin{array}{l}5 \\
3 \cdot 33\end{array}$ & $\begin{array}{l}18 \\
12 \cdot 00\end{array}$ & $\begin{array}{l}37 \\
24 \cdot 67\end{array}$ & $\begin{array}{l}47 \\
31 \cdot 33\end{array}$ & $\begin{array}{l}33 \\
22 \cdot 00\end{array}$ & $\begin{array}{l}8 \\
5 \cdot 33\end{array}$ & $\begin{array}{l}2 \\
1 \cdot 33\end{array}$ & $\begin{array}{l}150 \\
100\end{array}$ \\
\hline $\begin{array}{l}\text { Number expected } \\
\%\end{array}$ & $\begin{array}{l}9 \cdot 23 \\
6 \cdot 15\end{array}$ & $\begin{array}{l}45 \cdot 90 \\
30 \cdot 60\end{array}$ & $\begin{array}{l}46 \cdot 82 \\
31 \cdot 21\end{array}$ & $\begin{array}{l}28 \cdot 76 \\
19 \cdot 17\end{array}$ & $\begin{array}{l}15 \cdot 48 \\
10 \cdot 32\end{array}$ & $\begin{array}{l}3 \cdot 56 \\
2 \cdot 37\end{array}$ & $\begin{array}{l}0 \cdot 27 \\
0 \cdot 18\end{array}$ & $\begin{array}{l}150 \\
100\end{array}$ \\
\hline
\end{tabular}

$\chi^{2}=62 \cdot 293$. Degrees of freedom $=5 . P<0.001$.

Table $10 \chi^{2}$ goodness of fit test applied to mothers of less than 30 years of age and more than 30 years of age

\begin{tabular}{llll}
\hline & $<30$ & 30 and over & Total \\
\hline Number (sample) & 60 & 90 & 150 \\
$\%$ & 40 & 60 & 100 \\
1940 Number expected & 91.29 & 58.71 & 150 \\
$\%$ & 60.86 & 39.14 & 100 \\
1950 Number expected & 98.16 & 51.84 & 150 \\
$\%$ & 65.44 & 34.56 & 100 \\
1960 Number expected & 101.94 & 48.06 & 150 \\
$\%$ & 67.96 & 32.04 & 100 \\
\hline
\end{tabular}

1940 comparison, $\chi^{2}=27 \cdot 40$. 1950 comparison $\chi^{2}=42 \cdot 92.1960$ comparison $\chi^{2}=53 \cdot 85$. All 1 degree of freedom. All significant of $\mathbf{P}<0.001$.

1960), whereas the sample of patients were born over a wider time period when the pattern might have been different and changing. However, the distribution of the 3 census years of maternal age is basically similar, and since the arithmetic mean year of birth of the sample of 150 patients is 1949 and the median is 1951 it would seem appropriate to take the 1950 data as the most useful indicator of expected frequencies.
For comparison with 1940 data see Table 7, 1950 data Table 8, and 1960 data Table 9.

The $\chi^{2}$ test was also used to compare frequencies for mothers of less than 30 years of age and more than 30 years of age (Table 10).

There is therefore no doubt that the sample shows a statistically significant excess of older mothers as compared with that expected on the basis of the Registrar-General's data.

SOCIAL CLASS

The 55 patients entering the initial study were analysed in accordance with the current RegistrarGeneral's classification based on occupation: I professional, etc.; II intermediate; III skilled (N) nonmanual, (M) manual; IV partly skilled; V unskilled.

The Registrar-General's classification of occupations has a list of more than 20000 separate occupational titles which are grouped into 200 occupational units. The 4 housewives were classified on the basis of their previous occupations, and a prediction based on the subjects studied was used for students. 
The figures obtained were compared with figures from the $197510 \%$ sample (Economic Activity, Part 4). The results from the sample are shown in Tables 11 and 12.

These figures show the same tendency, but are even more skewed than the results of Karseras and Ruben $^{1}$ in that $76 \%$ of the patients come from social classes I and II. It is of course quite possible that people from these classes were more likely to offer to co-operate in a study of this nature. Also patients in social class $\mathrm{V}$ are often not paid if they are away from work, so are less likely to volunteer, which may well explain the absence of any patient from this class in the study. It can be argued that people from the higher social classes are more likely to get to Moorfields in that they are more active in seeking advice if their vision deteriorates in one eye and persist until they are referred. Nevertheless, despite all these considerations it would appear that there must be reasons why keratoconus patients tend to be of a higher social class than the general population. One possible answer is the age at which different social classes tend to have their children.

The Newsoms ${ }^{2}$ in a study of 700 families in Nottingham produced clear evidence that mothers are younger in the manual class. This can be seen not only in terms of earlier marriage, but also in

Table 11 Social class of patients in keratoconus sample

\begin{tabular}{llr}
\hline Social class & Number & $\%$ \\
\hline I & 16 & 29.09 \\
II & 26 & 47.27 \\
III N & 8 & 14.55 \\
III M & 4 & 7.27 \\
IV & 1 & 1.82 \\
V & 0 & 0 \\
\hline
\end{tabular}

$\mathrm{N}=$ nonmanual. $\mathrm{M}=$ manual. relation to the fact that the interval between marriage and the first birth (and to some extent subsequent births) is shorter for manual mothers than for nonmanual mothers. ${ }^{3}$

The percentage of mothers under the age of 21 at birth of first child by social class is shown in Table 13 (derived from Table XII Newsom and Newsom ${ }^{2}$ ).

\section{Discussion}

There is no doubt that keratoconus is a maternally age related condition and that this is reflected in the social class of the patients attending the Keratoconus Clinic of the Department of Contact Lens and Prosthetics, Moorfields Eye Hospital. There is still the possibility that Moorfields Eye Hospital attracts a rather atypical population, but the $\chi^{2}$ is so large that there must be a significant difference between the keratoconus sample and the general population. The finding of a maternal age factor does suggest that keratoconus is probably chromosomally determined. It is of course possible that the genetic mechanism may act synergistically with another mechanism such as allergy which may itself be independently genetically determined.

This paper is part of a doctoral thesis submitted to the City University, London. The work was carried out at the Department of Contact Lens and Prosthetics, Moorfields Eye Hospital, London, and was supervised by the Director, Mr C. M. Ruben, to whom I wish to record my thanks. I would also like to thank Mrs Kathleen Shawley for her assistance with the statistical analyses.

\section{References}

1 Karseras AG, Ruben M. Aetiology of keratoconus. Br J Ophthalmol 1976; 60: 522-5.

2 Newsom J, Newsom E. Infant Care in an Urban Community. London: Allen and Unwin, 1963.

3 Woolf M. Family Intentions. London: HMSO, 1971: Table 3.13.

Table 12 Social class of patients in keratoconus sample compared with general population (1975)

\begin{tabular}{llllllll}
\hline & $I$ & $I I$ & $I I I(N)$ & $I I I(M)$ & $I V$ & $V$ & All \\
\hline Keratoconus group & 19.09 & $47 \cdot 27$ & 14.55 & $7 \cdot 27$ & 1.82 & 0 & 100 \\
General population (1975) & 4 & 18 & 21 & 28 & 21 & 8 & 100 \\
\hline
\end{tabular}

Table 13 Percentage of mothers under the age of 21 at birth of first child: general population and keratoconus sample

\begin{tabular}{|c|c|c|c|c|c|c|}
\hline \multicolumn{7}{|c|}{ Social class (Registrar-General AB definition 1960) } \\
\hline & $I$ & II & $\operatorname{III}(N)$ & III $(M)$ & $\boldsymbol{I V}$ & $\boldsymbol{V}$ \\
\hline Mothers under 21 & 9 & 15 & 25 & 40 & 46 & 53 \\
\hline \multicolumn{7}{|c|}{ Comparing these with social class distribution in the keratoconus sample: } \\
\hline
\end{tabular}

